\title{
SUSTAINABLE DEVELOPMENT STRATEGY ON POULTRY INDUSTRY IN INDONESIA
}

\author{
Saptana ${ }^{1 *}$, Rahmat Fadhil ${ }^{2}$, Atika Dyah Perwita ${ }^{3}$ \\ ${ }^{1}$ Indonesian Center for Agriculture Social Economic and Policy Studies, E-mail: \\ saptana.07@gmail.com \\ ${ }^{2}$ Department of Agricultural Engineering, University of Syiah Kuala, E-mail: \\ rahmatfadhil@gmail.com \\ ${ }^{3}$ Entrepreneurship Lecturer, Faculty of Tarbiyah and Teacher Training, Walisongo State \\ Islamic University, E-mail: atikadyah@walisongo.ac.id
}

\begin{abstract}
ABSTRAK
Pembangunan industri perunggasan yang sudah berjalan selama ini di Indonesia yang lebih menekankan aspek pertumbuhan ekonomi, pada satu sisi telah berhasil meningkatkan produksi, namun pada sisi lain menimbulkan dampak negatif terhadap keberlanjutan usaha dan kelestarian lingkungan. Diperlukan reorientasi paradigma baru dari pembangunan industri perunggasan, baik dari segi arah, strategi maupun kebijakan. Tulisan ini bertujuan untuk mengulas keberhasilan dan kegagalan pembangunan industri perunggasan dengan pendekatan konvensional, paradigma pembangunan industri perunggasan berkelanjutan, konsep dan implementasi kemitraan usaha terpadu, serta perspektif ke depan. Hasil studi menunjukkan bahwa pembangunan industri perunggasan dengan pendekatan konvensional telah menimbulkan dampak negatif terhadap stabilitas dan keberlanjutan usaha, serta kelestarian lingkungan. Paradigma pembangunan industri perunggasan berkelanjutan dapat dijadikan strategi alternatif dalam upaya meningkatkan kesejahteraan peternak sekaligus tetap menjaga kelestarian lingkungan. Paradigma ini dapat berhasil baik jika diintegrasikan dengan strategi kemitraan usaha terpadu dari hulu hingga hilir. Untuk mendukung upaya ini diperlukan konsolidasi kelembagaan industri perunggasan dari hulu hingga hilir, sehingga tercapai keterpaduan proses produk dan antar pelaku usaha.
\end{abstract}

Kata-kata kunci : Pembangunan; Industri Perunggasan; Berkelanjutan; Kemitraan Usaha; Terpadu

\begin{abstract}
Development of poultry industry that had been running in Indonesia which more emphasized in economic growth aspect, on one side has succeeded in increasing production, but on the other side it caused negative impact toward business and environmental sustainability. A new paradigm reorientation of poultry industry development was needed in terms of direction, strategy and policy. This paper aimed to study the success and the failure of poultry industry development by conventional approach, paradigm of sustainable poultry industry development, concept and implementation of integrated business partnership, and future perspective. The results of this study showed that the development of poultry industry by conventional approach had generated negative impact toward business stability and sustainability, also toward environmental sustainability. The
\end{abstract}


paradigm of sustainable poultry industry development could be used as an alternative strategy in improving farmers welfare while maintaining environmental sustainability. This paradigm could work well if it was integrated with an integrated business partnership strategy from upstream to downstream. In order to support this effort, consolidation of poultry industry institutions from upstream to downstream was required, so that integration of product processes and between business people could be achieved.

Keywords: Development; Poultry Industry; Sustainable; Business Partnerships; Integrated.

\section{INTRODUCTION}

The profit sharing system in goat and sheep livestock or usually local people known as a "nggadoh" system, has long been found in rural Indonesia (Hikmah, 2019; Yunianto, 2015), also for beef cattle in rural Java (Saptana \& Ilham, 2016). In subsequent developments, most of the agribusiness livestock business partnerships, especially for broiler and layer cattle businesses, are carried out through a production sharing system with the existence of a written contract (Saptana \& Daryanto, 2013).

The growth of poultry industry in Indonesia, especially commercial poultry was high. As an illustration, in 2005, broiler meat production in Indonesia was 779,108 tons and increased up to 1,085,589 tons in 2012 or it increased by $9.06 \% / y e a r$. The growth was continue to increase, the production of broiler meat in 2016 reached 1,689,584 tons (Ditjen PKH, 2006; Ditjen PKH, 2013; Ditjen PKH, 2016). In 2005, egg production in Indonesia was 681,147 tons, it increased up to 1,059,266 tons in 2012 or increased by $6.80 \% / y e a r$. The growth was continue to increase, in 2016, egg production reached 1,428,195 tons (Ditjen PKH, 2006;Ditjen PKH, 2013; Ditjen PKH, 2016). By succeeding in increasing commercial poultry production, it could be stated that Indonesia had been able to meet the needs of broiler meat and domestic chicken egg (Puskadagri, 2016; (Saptana \& Yofa, 2016). The development of high production was supported by the development of the upstream (breeding farm and feed mill), cultivation, and downstream industries (meatshop, processing industry, and culinary industry).

The successful of poultry industry development had negatively impacted business stability and sustainability, and had negative impact on the quality of the surrounding environment. As an illustration, poultry industry that relied on natural resources potency asraw feed materialssupplier (corn) removed other food commodities. As a result, after 
almost five decades, poultry industry development still faced with the following problems: (a) Decreased of fertility and productivity of fields in producing raw feed materials, while carbon content in the soil was only $2-3 \%$ of the fields; (b) Reduced of environmental carrying capacity around commercial farms; (c) Increased of poultry farms phenomenon made people stop and go bankrupt; (d) Widespread outbreaks of animal diseases, especially avian influenza; (e) Increased of pollution and environmental damage; (f) Reduced of revenueper output unit generated; and (g) The occurrence of socio-economic disparities between small scale and large scale farms.

The problems arose because the direction of poultry industry development from time to time tended to capital-intensive business, even though in 1975-1995, the government had intervened in technological, business scale limit and marketing aspect (Ilham, 2015; Yusdja et al., 2004). Government policy which was biased in the growth of production growth and the dominancy of private sector role had negatively impacted the existence of small scale farmers and environmental damage. Farmer community had a bigger role as the object rather than as the subject in poultry industry development. The poultry industry was no longer placed as the foundation of people's economy, but as a buffer to succeed industrialization as a locomotive of economic growth. Broiler industry, which in the early 1970s was dominated by public farms (85\%) and only $15 \%$ were owned by private business, was reversed currently. Large scale private farms own $85 \%$ of broiler production and only $15 \%$ were owned by small scale farms. Poultry industry sector playes a role in boosting domestic animal food production rapidly and did not have any political risk. This economic development pattern often referred as "conventional development pattern". Nowadays, the pattern was considered obsolete, it even could cause negative impacts and trigger conflicts between communities, so that alternative patterns needed to be submitted.

Alteration of strategic environment in the form of economic globalization, climate change, decentralization, democratization, dynamic of market demands and change in consumer preferences, and environmental sustainability required an adjustment of poultry industry operation. Economic globalization caused the higher integration of various aspects of a state economic and world economic, as well as increasing 
competition between business people and between countries. It was estimated that the impact of globalization would increase the competition not only between business people, but also between product supply chain. Decentralization policy was expected to affect industry developmentperformance of national industrial, in upstream, cultivation, and downstream industries. The flow of democratization would increase conflict intensity in the society if it was not managed well and properly. Nowadays, the intelligent consumers were no longer bought commodities, but bought products with more complete and detailed attributes.

Based on these problems, a new paradigm of poultry industry development is needed, in the direction, strategy and operational policy, so that various problems could be resolved without causing business congestion, conflicts between society groups, and damage to natural resources and environment.

\section{RESEARCH METHOD}

This article, on one side tried to review the success of poultry industry development through conventional approach and on the other hand to review the negative impact it caused. The paradigm of sustainable poultry industry development and integrated business partnership strategy was intended to be able toactualize the development of poultry industry which wascompetitive and sustainable.

\section{RESULTS AND DISCUSSION}

1. Growth Bias Policy and Threat of Unsustainable Poultry Industry

Development of poultry industry which was only oriented to the acceleration of economic growth and profit only did not concern toward equity and environmental sustainability aspect resultingin a negative impact on business sustainability and environmental quality. The following descriptions, present several cases of poultry industry development failure in Indonesia.

a. Policy bias toward growth direction

The sources of commercial broiler and layer industries growth in Indonesia in terms of demand were determined by population and growth factors, income levels, urbanization phenomena and market segmentation, and consumer preferences (Daryanto, 2009; Saptana et 
al., 2017; Saptana \& Daryanto, 2013). Census of population in 2010 showed that total population of Indonesia was amounted around 237.64 million people (BPS, 2010), then in 2016 the population reached around 257.91 million people, in July 2017 Indonesia population was estimated more than 262 million people (Tribunnews, 2017). The large population and positive growth of $1.38 \% /$ year (2010-2015) caused the increasing of livestock products demand. Broiler and egg products were classified as high-value products, so the higher the income the higher the demand. The increasing of urbanization flows from rural to urban and from agriculture to industrial and service sectors had increased chicken and egg products demand in downtown and industrial centers. The increasing of the upper-income share especially in urban and industrial areas had led to the increasingof chicken and egg products demand. The dynamic of alteration consumer preferences from red meat to white meat had increased the share of chicken meat demand.

On the supply side, the influencing factors were the availability and price of day old chick (DOC), availability and price of feed, techonology changes (genetic, feed and logistic), land/cageavailability, labor availability and wage rates, clean water availability, availability and price of energy, and conducive policy (Daryanto, 2009; Saptana et al., 2017; Saptana \& Daryanto, 2013). Until now, most policies related to poultry industry tend to be biased and aimed to encourage the growth of poultry production. The concern toward equity and sustainability aspect is still lacking, government even show a tendency to devolve it entirely to the market mechanism, where in the market is highly distorted.

There are several laws and regulations related to the development of poultry industry in Indonesia. Law No. 1 of 1967 concerning Foreign Investment and Law No. 6 of 1968 concerning Domestic Investment, encouraged to increase poultry industry investment, in upstream, cultivation and downstream industry (Saptana et al., 2017; Saptana \& Yofa, 2016). The poultry industry, especially the upstream and cultivation industries which initially highly concentrated in Java, had been spreading to Sumatra, Sulawesi, Kalimantan and other areas (Figure 1). Meanwhile, the downstream industry is still concentrated in 
Java Island.

Along with the growth of large scale poultry company which was starting to replace the existence of small scale poultry farms, the government issued a Presidential Decree No. 50 of 1981 concerning Business Development of Chicken Farm. This policy could be regarded as a policy that pro small scale poultry farm and gave a new hope. This Presidential Decree prohibits the operation of poultry farms with more than 5000 layer chickens and more than 750 broilers per cycle. This condition required companies that already had large scale business to close their business and diverted it into other businesses such as breeding farm, feed mill, and processing industry. This policy had caused the concern of the fund owners and could cause them a huge losses.

Figure : Map of Indonesia includes Java, Sumatra, Kalimantan, Sulawesi and other islands (CIA World Factbook, 1998)

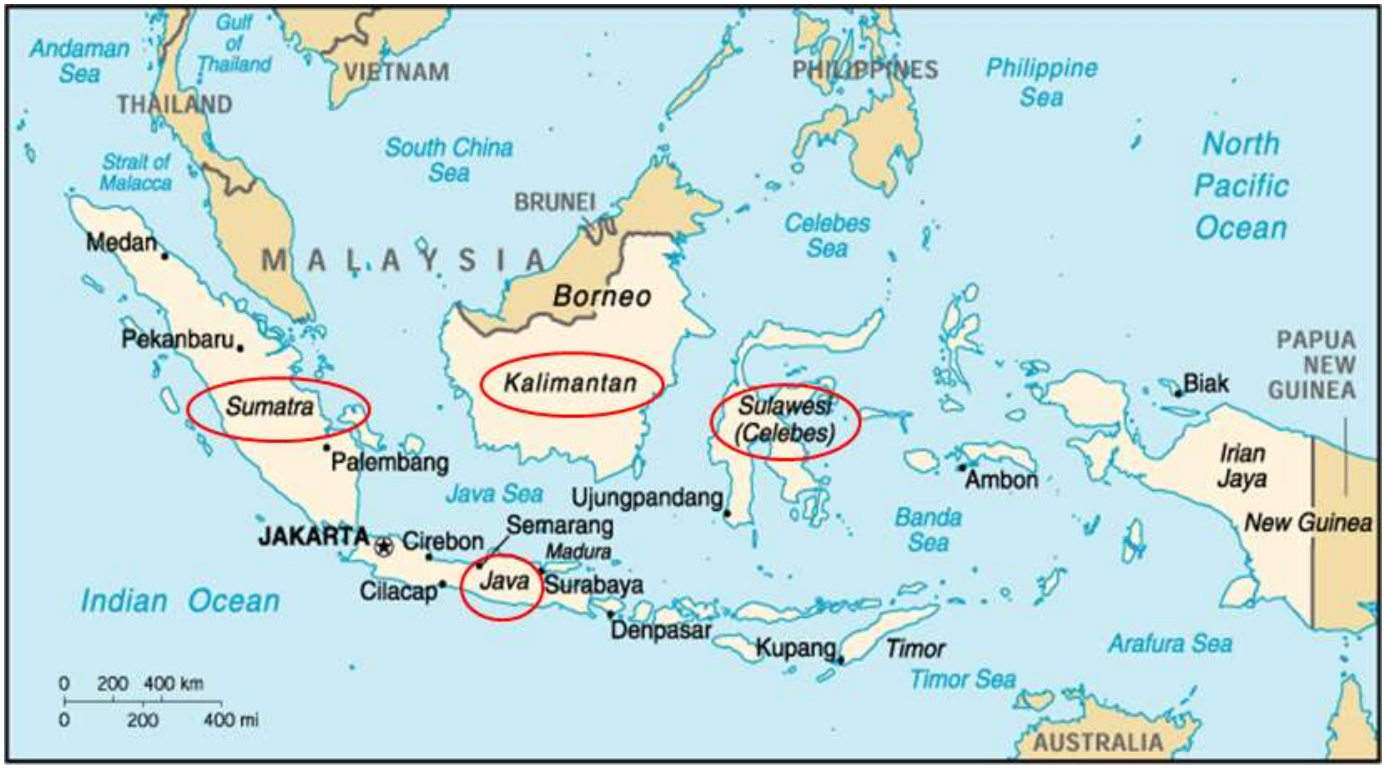

The government encourages the growth of cooperatives among small scale farmers by adding credit fund support to accelerate the development of the farms. In order to succeed the government's political will, the poultry mass guidance programme was issued and Bureau of Logistics (BULOG) was assigned to stabilize the price of chicken and egg products, to improve distribution and marketing 
efficiency, cooperative development, market operation, and to control the price of chicken and egg (Yusdja et al., 2000) ; Puskadagri, 2016). But this support was relatively limited to intervene the existence let alone remove the position of large scale poultry company.

Implementation of this policy did not go as expected, even small scale farmers increasingly lost the opportunity to maintain and continue their business. This result was induced by these following accounts (Yusdja, 1984); Puskadagri, 2016): (a) limitation of business scale according to the Presidential Decree to the level of unprofitable business, so that it could not guarantee the development of small scale farmers; (b) small scale farmers generally did not have sufficient fund and maintainingpoultry farm was far below the small scale farm economic, that is $<1,000$ heads; (c) Bimas credit had a very small scale, where a farmer would only get 500 chickens, so theywould not be able to return the credit; and (d) the government was unable to control the market effectively.

One of the government policy which was considered pro small-scale farmers had failed to be implemented effectively. The government tried to make a new policy through the improvement of poultry industry structure through Core Estate and Smallholderknown as PIR Poultry. The purpose of this policy was to protect small scale farmers, but indirectly accept the presence of large-scale poultry company. The pattern of PIR poultry was a business partnership structure between the core companies and small farmers. The core company served as a provider of input and marketing, which was in charge of procuring inputs and accommodating the poultry products such as chicken and egg. Meanwhile, farmers played a role in implementing the farms appropriately according to technical guidance and core companies management. Farmersshould pay the input they bought by with the proceedsthey earned. The price of poultry product per unit was determined by mutual agreement, but itwas still profitable for the farmers. Conceptually, farmers received market guarantees and price certainty.

In reality, the performance of PIR Poultry did not show the condition as government and small scale farmers expected. Most smallholder farmers in this period run into bankruptcy (W. Rusastra et 
al., 1988). So, it could be conclude that the market mechanism had already formed too strong to be changed. The government lost direction in controlling the development of poultry industry. Year 1987 was known as a concern year for small scale farmers. DOC price fluctuation, rising feed pricethat kept going, and the sharp fluctuation phenomenon in output price made small-scale farmers into a very difficult situation.

Law No. 22 of 1990 on Business Development of Poultry Farming and Decree of the Minister of Agriculture No.472 of 1996 which was a technical guidance, stated that: (a) a poultry farms withless than 15,000 chickens did not require permit except to report to local Department of Animal Husbandry office; and (b) large scale poultry companies are permitted with the condition that they had to conduct business partnerships with small scale farmers, within three years the portion of small-scale farmers is bigger, and at least $65 \%$ of production is for export, especially for Foreign Investment. Large scale companieshave to request permission to the Minister of Agriculture. The implementation of policy in the field was not going as expected, the requirement for large companies to export $65 \%$ of their production was never realized and sold to domestic market, as a consequense it destroyed small scale farmers. Presidential Decree 22/1990 was finally revoked and the government issued Presidential Decree 85/2000 aimed to provide assurance of business certainty, sense of justice, and to improve efficiency and competitiveness of poultry industry in the trade liberalization and economic globalization era. Ilham (2015) stated that with the presence of this regulation, the government no longer intervene in regulating the industrial structure of poultry farming. It could be said that this policy tended to be biased toward large scale company and paid less attention toward small scale farmer and environmental sustainability.

Presidential Decree No. 5 of 1999 concerning Prohibition of Monopolistic Practice and Unfair Business Competition, those are regulating prohibited agreements (oligopoly, price fixing, territorial division, boycott, cartel, trust, oligopsony, vertical integration, agreements with foreign parties), prohibited activities (monopoly, monopsony, market control, conspiracy), dominant position (multiple 
positions, share ownership, merger, consolidation, requisition), Commission for the Supervision of Business (KPPU), case handling procedure, sanction, and other provision. This decree was aimed to protect business people including small scale farmers from monopolistic practice and unfair business competition.

Government policy which was unfocused in inducing the growth of poultry production had encouraged large scale livestock company to grow toward oligopolistic industrial structure in input market, oligopsonistic market structure in output marketwhen facing withsmall scale farmer, and oligopolistic market structure in output market when facing with collector merchant and wholesaler in the market (Saptana et al., 2017); Puskadagri, 2016). KPPU stated that Indonesian poultry industry was dominated by two big players with a share more than 70\% (KPPU, 2016). The result of KPPU reasearch also showed that there was an imbalance of margin distribution among business people in every supply chain of broiler. Although KPPU had conducted a trial regarding unhealthy competition practice and cartel in the poultry industry for several times, but they failed to prove that cartel was really happened.

Regulation of the Minister of Agriculture (Permentan) Republic of Indonesia No 381/Kpts/OT.140/10/2005 concerning Veterinary Control Certification Guidelines of Food Business of Animal Origin and Guidelines of Food Safety, Quality and Nutrition of Animal Products, validated to protect consumer of animal food products circulating in the market, so that consumer could get a safe and good quality animal food products. Nowadays, the consumer demand a more complex, and more complete and detailed product attributes, such as security attribute, nutritional attribute, value attribute, packaging attribute, environmental attribute, traceability attribute, and humanism attribute (Simatupang et al., 1998). In developed countries, animal welfare attribute evenhad been demanded (Daryanto, 2009), for example the case of the discontinuation of Brahman Cattle export from Australia to Indonesia due to the Slaughterhouse was considered to did not concerned about animal welfare.

Law no. 18 of 2009 on Animal Husbandry and Animal Health, had arranged about resources, animal husbandry, animal health, 
veterinary public health and animal welfare, veterinary authority, empowerment of farmers and businesses in animal husbandry and animal health, human resources development, and research and development. The principle of this law is intended to make the Indonesian animal husbandry industry to be advanced, competitive, and sustainable. However, counterproductive occured because one article, namely Article 2 which gave the opportunity for large scale companiesto dominate themarket. In practice, large investors was taking advantage of Article 2 to dominate the market either through vertical or horizontal integration.

Government Regulation (PP) No. 4 of 2016 concerning the Entry of Livestock and / or Animal Products Originating from Their Country of Origin or a Zone Within Their Country of Origin Under Certain Circumstances, allowed the entry of live animals and animal products from a country or territory of a country that did not free from animal diseases. This policy was biased toward the importer and trader companies, and made domestic farmers with livestock and animal products to confronts with similar products from abroad. Domestic consumers was benefited from the availability of livestock products, but the safety and quality aspects were not fully guaranteed.

b. The impact of policy on poultry industry performance

In general, the impact of government policy on poultry industry performance had encouraged the growth of upstream, cultivation and downstream industries, but the policy had showed a negative effect on the stability and sustainability of small scale farmers and environmental pollution. The results of a study in Thailand showed that the level of biosecurity application in contract farming pattern was better than cooperatives farming and individual farming (Wei \& Aengwanich, 2012). The results of a study in West Java, Indonesia revealed that most small scale chicken farmers who partnered with a livestock or poultry shop companies did not apply biosecurity properly, with the values ranging from 7.7-16.7 (Martindah \& Basuno, 2014). The reason was that business partnerships which was builttended to be profit sharing and had not included risk-sharing aspect, resulting in less partner farmers had a sense of responsibility for the control of disease and less aware of the importance of recommended biosecurity 
application. For the farmers, applying biosecurity means to increase production costs, both for the procurement of tools, drugs, and labor.

The research results in several ASEAN countries revealed that compared to several other ASEAN countries such as Malaysia, Thailand and Philippines, the price of broiler production cost in Indonesia was relatively higher (Aho, 1998; Tangendjaja, 2010). The cost of producing $1 \mathrm{~kg}$ of chicken meat in Indonesia costs was 0.80 US\$, while in Malaysia was only 0.63 US\$, in Thailand was 0.50 US\$ and in Philppineswas 0.62 US\$. The market price of live broiler per $1 \mathrm{~kg}$ in Indonesia reached 0.91 US\$, while in Malaysia was only 0.71 US\$, in Thailand was 0.75 US\$, and in Philippines was 1.0 US\$. This study showed that Indonesia had only excelled against Philippines and unable to compete against Malaysia and Thailand.

c. Threat of poultry industry unsustainability

Damage of natural resources and environment were largely triggered by two factors, namely consumption patterns and policy failure (Fauzi, 2009). (Parikh et al., 1996) conducted a study of the linkage between consumption patterns and environmental degradation, it showed that developed countries with only $24 \%$ of the world's total population consumed $50-90 \%$ of world commodities. The high levels of per capita consumption in developed countries should be met not only from developed countries, but also from developing countries through international trade and the role of multi-national corporation. According to (Aziz, 1991), environmental problems arised byeconomic activity could be divided into two groups, namely the issue of environmental pollution and the problem of natural resources.

The impact of government policy which biased toward pursueing economic growth also affectin the dominance of large scale companies and increasingly replace the position of small scale farmers. In 2014, the production of broiler chicken of integrated large scale company was estimated dominating the market $>85 \%$ and had reached up to more than 2.5 million tons (Puskadagri, 2016). The production structure of broiler industry in Indonesia was dominated by large scale companies integrated with $85 \%$ of market share and the rest (15\%) were independent farmers (Puskadagri, 2016). Small scale farmers in 
Indonesia faced the oligopoly market structure in input market and oligopsony in output market. In smallholder input markets,small scale farmers were facing a led market oligopoly structure and only as a price recipients, while breeding companies and feed manufacturers as a price determinants followed the company's lead policy (Saptana \& Yofa, 2016). Furthermore, it was suggested that the market of breeders partners were guaranteed, but with limited profit, with the requirement to do farming on technical and management standard recommended by the core company. Meanwhile, small scale individual farmers were faced with a fluctuate market situation. This condition caused small scale farmers to be marginalized. These negative impact problem should be solved, a conducive policy mechanism was needed to encourage integrated livestock companies to penetrate global market, meanwhile for small scale farmers,protection policy to maintain their sustainability was need.

The study by (Fitriani et al., 2014b) and (Fitriani et al., 2014a) showed that there was a simultaneous relationship between the structure, behavior, and performance of broiler industry in Indonesia, wherein integration had a positive and significant relation toward concentration. It was stated that the increasing of integration would decrease per unit cost and increase market power. Furthermore, market forces had a positive impact on prices, it mean that there was a monopoly power in broiler industry which was able to affect the price in market. The study by (Saptana et al., 2017) on broiler production and marketing aspect showed that the price of broiler at farmers level and at wholesale level was not well integrated, while market integration at wholesaler level and at retailer level was relatively more integrated. The absence of integration at broiler market was due to the current price of broiler tended to follow the price of Coordination Station (POSKO) determined by PINSAR Institutional (Market Information Center) which was a container of large scale companies in determinating a joint strategy. POSKO price was traders benchmark price in redeeming broiler from farmer partners in integrated companies.

POSKO is a joint secretariat which was made as a place among the representatives of large scale livestock companies in each region 
(province) to coordinate, especially in determinating and it is a place forannouncing live broiler selling price in farmers who had become partners with the company. POSKO price was used as a reference for collectors and wholesalers to redeem the price of delivery order (DO) to the company in cattle farms. Institutional PINSAR was initially an independent institution that provided data and market information related to poultry industry, of DOC price, feed price, live broiler price, chicken meat price, and egg price. Nowadays This institution tended to be an extension of large scale livestock companies in providing market data and market information related to poultry industry for the benefit of large scale livestock companies.

Establishment of live broiler price at the producer level (large scale companies and independent farmers) was largely determined by the oligopoly force that tended to form cartel through POSKO price as the benchmark price for redemption of merchant/broker traders and wholesalers. In live broiler market, the influence of supply and demand factors was relatively small, while the formation of chicken meat price at retail market level had significant influence. In general, market mechanism of chicken meat was less competitive and integrate, except in broiler central areas and also corn production central areas.

Poultry industry policy which was biased in pursueing economic growth and spur of poultry production also had an impact on the widespread outbreak of animal diseases. The study by Ilham and Yusdja (2010) concluded that: (1) location of the poultry affected the level of avian influenza outbreaks, (2) the sustainability of poultry business was affected by the level of the outbreaks, the type of poultry maintained, and the pattern of its cultivation, (3) aggregately, the impact of avian influenza cause a decrease in the share of income from poultry farms, and (4) the rate of attack, the condition of infection, and the time of the avian influenza epidemic attack affected the production of meat and egg. The study by (Muryani et al., 2012) showed that the spread of avian influenza was influenced by environmental factors i.e. physical environment, biology and social environment. The study by (Rodríguez et al., 2006) revealed that avian inflammation had a serious impact toward world economy, especially poultry industry and poultry-related industry. The study by (Saptana et al., 2005) on the 
impact of avian influenza toward poultry industry performance in Central Java Province showed several results, those were: (a) the decrease of DOC production volume up to $(40 \%)$ and the decrease of DOC selling price up to $(70 \%)$; (b) the decrease of feed production volume up to $(14,58 \%)$, but no effecton decreasing of feed selling price; (c) the decrease of feed poultry shop (PS) sales volume up to $(40 \%)$; (d) the number of poultry farmers who went bankrupt (30-40\%); (e) the number of live broiler slaughterwas reduceup to $(40 \%)$; and (f) the decrease in broiler meat sales volume up to $(60 \%)$.

The biased policies had inducedthe economic growth but did not paid attention to equity and sustainability aspect, thereby it negatively impacted the existence and sustainability of small scale farmers businesses. The study by (Wang et al., 2014) in China, and Wei and (Wei \& Aengwanich, 2012) in Thailand stated that the development of Poultry Production Cluster (PPC) were conducted in order to restructure poultry industry. The results of (Ilham, 2015) study on government policy on small scale poultry farm and environmental health in Indonesia stated that PPC was relatively close to human settlement (0-20 meters) and several > 500 meters, with limited supervision and control of environment. Supervision and control over good environmental could avoid conflict which means maintaining the existence and sustainability of PPC. At certain PPC sites, the compaies and the farmers provided compensation assistance in the form of chickens, road repair and fund donation for social activities. Most of the residents around the farms had adapted, so that the farms could continue go on.

2. Sustainable Development Paradigm and Integrated Business Partnership

a. Sustainable development paradigm

In 1987, the World Commission on Environment and Development, or known as the Brundtland Commission, published a book entitled Our Common Future which gave attention toward sustainable development (Fauzi, 2009). The Brundtland Commission defined sustainable development as development that meets the need of the current generation without diminishing future generationability in fulfilling their needs. Furthermore, stated that market friendly 
economic policy was a "neccessary condition", while environmental friendly economic policy was a "sufficient condition" for Indonesia economic development.

Sustainable development as an effort to maximize the net benefit of economic development conditions that it can maintain and improve service, quality and quantity of natural resources all the time (Saptana \& Ashari, 2007; Turner et al., 1994). The study by (Saptana \& Ashari, 2007) showed that conventional agricultural development in Indonesia had impacted several cases of agricultural development in food crops, forestry and fisheries. Furthermore, the Agricultural Research Service (USDA) defined sustainable agriculture as a future agriculture that can compete, productive, profitable, conserve natural resources, protect the environment, and improve health, food quality and safety. Sustainable development should be directed towards eradicating poverty (economic targets), social equity (social targets) and environmental sustainability (environmental targets) (Salim, 2005).

Basically, sustainable agriculture development was an implementation of sustainable development concept that aimed to increase the income and welfare of farm community widely. This was conducted through increasing agricultural production (quantity and quality), while maintaining the sustainability of natural resources and environment (Fadlina et al., 2013). FAO (1989) stated that sustainable agriculture is a natural resource management and technological and institutional change to ensure the fulfillment and satisfaction of human needs sustainably for present and future generations. Development of agriculture, animal husbandry, and poultry industries should be able to conserve soil, water, plants and animals, and technically efficient, economically profitable, socially acceptable and ecologically harmless to the environment. Sustainable development is a systematic and planned way of view of activities in order to improve the welfare, quality of life and environment without diminishing the access and opportunity for future generations to enjoy and utilize it (Budimanta, 2005).

Several definitions mentioned above led to several implications of poultry industry development with environmental insight, namely: (a) Ensure the sustainable fulfillment of basic needs of nutrition, especially 
for animal food products for the community, both for present and future generations; (b) Providing decent employment and income for farmers which is able to provide an ideal welfare; (c) Maintaining poultry production capacity which has environmentally insight; (d) Reduce the impact of poultry industry development activities that can lead to pollution and degradation of environmental quality, and (e) Produce various poultry products, both chicken and egg products and processed products, which are safe, qualified and highly competitive.

b. Sustainable development and importance of integrated business partnership.

The structure of poultry agribusiness that developed these days could be classified as dispersal type or insulated, less competitive, and unsustainable. According to (Simatupang, 1995) this was caused by three factors, namely: (a) there was no harmonious functional relationship between agribusiness activities and agribusiness people, so that market dynamics could not be responded effectively due to the lack of coordination; (b) double margins was formed so that the cost of production, processing, and marketing which should be paid by consumers become more expensive resultingin inefficiency of system; and (c) the absence of equality in bargaining position between farmers and other agribusiness people, so that farmers found it difficult to get a fair market price. Furthermore, it was proposed that there were two coordination system, that is coordination through market price and between agribusiness people. The first system could not guarantee product integrity, while the second system could ensure product integration. Conceptually and operationally, the coordination system could be performed through business partnership between agribusiness people in poultry industry.

There are at least three patterns of broiler farms in production center areas in Indonesia, i.e. the pattern of individual farm (15\%), internal business partnerships $(45 \%)$ and external business partnerships (40\%) (Puskadagri, 2016; (Saptana et al., 2017) ; (Saptana \& Yofa, 2016). Furthermore, it was disclosed that in individual farmpattern, farmers got supplies from Poultry Shop (PS) and other suppliers. In internal business partnership pattern, input supplies (DOC, feed, medicines and vaccines) was obtained from feed mill companies as core companies. In external business partnerships pattern, 
partner farmers got input supplies from the company financiers (core companies) who become their partners. In internal partnership pattern, the selling price of the output is usually determined through contract mechanism, whereas internal partnership is determined through contract mechanism and some internal partnership go with market price.

Development of sustainable poultry industry through agribusiness system partnership approach provided several benefits at once, namely: (a) optimizing resource allocation at one time and generation, (b) improving the efficiency and productivity of poultry industry through product integration based on dynamics of market demand and consumer preference, (c) improving the efficiency of each supply chain and harmonizing inter-system linkages through alignment between two parties, (d) developing agribusiness partnerships which is mutually beneficial, reinforce and beneficial, and (e) increasing market access with a guarantee of stability and business continuity for small scale farmers.

3. Integrated Business Partnership Strategy

Sustainable agricultural development (poultry industry) had three targets namely economic targets (efficiency and growth), social targets (ownership/justice), and ecological targets (sustainability of natural resources and environment) (Salim, 2005); (Saptana \& Ashari, 2007). These three targets were interrelated and interplay with one another. Sustainable poultry industry development could be realized if the three development targets were achieved.

Efficiency and growth of poultry industry could be encouraged through the growth of poultry production (chicken and egg), farmers revenue and other business people, fund formation, and the increasing of added value and the enhancing of product competitiveness. In this economic target, poultry industry could be statedsuccessful which was shown bythe increase of production, both chicken and eggs were high. Under normal conditions, it could be said to achieve self-sufficiency, downstream industries especially based on poultry products began to develop, but until it did not able to penetrate export market.

Equitable of resource ownership in the upstream, cultivation and 
downstream industry showed a very high inequality. It coulf be stated that business ownership in upstream and downstream industries almost entirely controlled by large scale livestock companies. Both internal and external business partnerships involved a large number of farm households. In addition, the growth of culinary industry based on animal products which largely driven by people's economy also experienced a rapid development. Moreover, the growth of cake industry using raw materials or materials from chicken and egg also experienced a significant growth. Meanwhile, in cultivation aspect,around $85 \%$ was controlled by integrated livestock company either through its own cultivation or through business partnership and only around 15\% was controlled by individual farmers. The study by (Bahari et al., 2016) on contract farming of broiler farms, showed that implementation of contract farming had positife result in improving technical efficiency, lowering production costs, and increasing partner farmer income.

The sustainability of agricultural and environmental resources could be realized by developing environmentally friendly farming system, maintaining and improving the quality of surrounding environment, mitigating external negative impact, and encouraging external positive impact in development process.Small scale farmers, both individual farmers and business partnerships patterns wereone option to reduce the level of poverty and unemployment by opening job vacancy. The government cooperated with large scale livestock companies to maintain small scale farmers existency and sustainability by utilizing technology to improve business efficiency and build integrated business partnerships. This was directed to keep the animals safe, produce poultry products that was safe for consumption and maintain environmental health.

Institutional farmer groups, both farmer group who will be incorporated in agribusiness associations/cooperatives agribusiness and who will conduct business partnerships, needed to consolidate in membership, management, and fundaspects. Institutional groups of small-scale individual farmers in the future at least should be able to transform themselves from livestock institutional with horizontal bond only to market-oriented livestock institutional and vertically integrated,could be in the form of agribusiness cooperative or Village-owned enterprise (BUMDES) with legal status. 
Implementation of sustainable poultry industry development through integrated business partnership in Indonesia should be encouraged to coordinate vertically through upstream to downstream business partnerships (Tangendjaja, 2010). If poultry company had a feed factory, it was encouraged to establish chicken breeding and if there was a chicken breeding, it was encouraged to establish a contract farming and processing industry and culinary industry. If large investors did not have animal feed and animal breeding industries, they were encouraged to build breeding and feed factories. If the integrated business partnership institution could be conducted properly, then the company could develop a slaughterhouse (RPU) and proceed the poultry products into processed or culinary products which add a positive value with their own brand in order to sell directly to consumers.

\section{CONCLUSIONS}

The shift in development patterns from conventional patterns toward sustainable development was increasingly accepted by many countries as a logical consequence of international community awareness of quality, safe and environmentally friendly products. The shift of paradigm toward sustainable poultry industry development could not be implemented in short and partial term, but it was a medium-long term, performed integratedly, andthorough from upstream to downstream.

The policy which was deemed appropriate in Indonesia was sustainable poultry industry development through an integrated business partnership. This policy could ensure economic growth, social equity or equitable distribution aspects, job vacancy and environmentally friendly. In cultivation subsystem, Poultry Production Cluster (PPC) could be applied by approaching with engineering and management system of livestock that pay attention to technical-economic, social equity, and environment-friendly aspects. Upstream and downstream industries should be conducted efficiently, so it could reduce production cost and produce a good quality product. In the whole poultry industry from upstream, cultivation and downstream wereconducted by minimizing the minimum waste generated, managing waste properly, and building integrated business partnerships that were mutually beneficial, reinforce and profitable. 
Sustainable poultry industry development through integrated business partnerships development would only succeed if it was performed participatively by involving stakeholders from planning process, implementation, and monitoring and evaluation. In this way, stability and continuity of production, income, and business continuity were expected to be achieved

Sustainable poultry industry development through integrated business partnership strategy required consolidation from farmer institutions, both individual farmers and partner farmers. In the early stage, consolidation of farmerswas conducted in group with legal status. The group of farmers then consolidated themselves in a form of combination farmer groups (gapoktan) or farmers association/cooperative poultry agribusiness. The next step was to consolidate business management on the region or production clusters that met the scale of economic enterprises. A sustainable integrated business partnership system was run by applying the corporate management. The selection of partner companies was based on recommendations from the District Animal Husbandry Office or Directorate General of Animal Husbandry and Health based on its commitment to establish an integrated, sustainable and integrated business partnership.

Sustainable poultry industry development through integrated business partnership was expected to provide several benefits, those are: (1) increasing poultry production moderately, stably, and sustainably, (2) increasing the income and welfare of farm households, (3) alleviating poverty and reducing unemployment in rural areas, (4) improving equity and social justice through the expansion of employment opportunities and employment, (5) increasing the efficiency of scarce resources allocation (fund investment, seed, feed, medicine, and labor), (6) increasing the participation and empowerment of farmers both individual farmers and partner farmers, and (7) maintaining health and environmental sustainability to support sustainable poultry industry development activities.

The policy peole farming development, both in individual farmers and internal and external partnerships pattern should be continued with some improvements. Given the limited of government funding budget, the empowerment activities of individual farmer groups was focused on 
selected groups. These groups were expected in medium term of time could grow and develop into integrated companies in agribusiness associations or agribusiness cooperatives which also had breeding, poultry feed, slaughterhouse (RPU), and chicken stall businesses, so they could compete in the market, both in domestic and global markets. For the farmers who could not afford to form an integration company would be directed to be "contract grower" or partner farmers in an integrated business partnership system. It was expected that at least partner farmers could work on $5000-6000$ heads for one family so that they could live propery.

Some of the policies that governments could undertake were: (a) Policies that encourage the increasing of investment in upstream, on-farm, and downstream poultry industries; (b) Prepare a more accurate balance sheet of poultry commodity production, supply, supply and stock accurately at national, provincial and district levels, so that the production planning can be performed well; (c) Provide accurate and up-to-date data on DOC production and livestock feed, in relation with production planning; (d) Provide technical and management guidance and facilitation of budget allocations for small scaleindependent farmers are able to maintain 5000-6000 heads; and (e) Infrastructure development (RPU, market, road, energy, clean water, layout and license), (f) Strengthening of farmer groups, whether incorporated in agribusiness associations/cooperatives or those undertaking integrated business partnerships; and (g) Product development and promotion of poultry products.

\section{REFERENCES}

Aho, P. (1998). How Globalization of Agriculture will Affect The Poultry and Livestock Industries of Southeast Asia. ASA Technical Bulletin, 39.

Aziz, I. (1991). Ekonomi Sumber Daya dan Lingkungan Dalam Konsep Pembangunan Berkelanjutan (Resources and Environment Economic in Sustainable Development Concept). Prisma, 1.

Bahari, N., Mustadjab, M. M., Hanani, N., \& Nugroho, B. A. (2016). Analisis Contract Farming Usaha Ayam Broiler. Jurnal Agro Ekonomi, 30(2), 109. https://doi.org/10.21082/jae.v30n2.2012.109-127

BPS [Badan Pusat Statistik]. (2010). Data Sensus Penduduk (Census Population 
Data). Badan Pusat StatistikIndononesia. Jakarta. (in Indonesian).

Budimanta, A. (2005). Memberlanjutkan Pembangunan di Perkotaan melalui Pembangunan Berkelanjutan dalam Bunga Rampai Pembangunan Kota Indonesia dalam. In Budhy Tjahjati Sugijanto Soegijoko (Ed.), Bunga Rampai Pembangunan Kota Indonesia dalam Abad 21 (p. 330).

CIA World Factbook. (1998). Indonesia. WorldRover, (source http://www.worldrover.com/vital/indonesia.html).

Daryanto, A. (2009). Dinamika Daya Saing Industri Peternakan. IPB Press. https://repository.ipb.ac.id/handle/123456789/42658

Ditjen PKH. (2006). Statistik Peternakan dan Kesehatan Hewan Tahun 2006 (Livestock and Animal Health Statistics of 2006). Direktorat Jenderal Peternakan. Kementerian Pertanian. Jakarta.(in Indonesian).

Ditjen PKH. (2013). Statistik Peternakan dan Kesehatan Hewan Tahun 2013 (Livestock and Animal Health Statistics of 2013). Direktorat Jenderal Peternakan. Kementerian Pertanian. Jakarta.(in Indonesian).

Ditjen PKH. (2016). Statistik Peternakan dan Kesehatan Hewan Tahun 2016 (Livestock and Animal Health Statistics of 2016). Direktorat Jenderal Peternakan. Kementerian Pertanian. Jakarta.(in Indonesian).

Fadlina, M. I., Supriyono, B., \& Soeaidy, S. (2013). PERENCANAAN PEMBANGUNAN PERTANIAN BERKELANJUTAN (Kajian tentang Pengembangan Pertanian Organik di Kota Batu) Sustainable Development of Agrocultural (Studies on Organic Agricultural Development in Batu City). J-PAL, 4(1). https://jpal.ub.ac.id/index.php/jpal/article/view/115

FAO [Food and Agriculture Organization]. (1989). World. The State of Food and Agriculture. Food and Agriculture Organization of the United Nations, Rome, Italy.

Fauzi, A. (2009). Sinergi antara Pembangunan Ekonomi dan Pengelolaan Sumber Daya Alam dan Lingkungan. Jurnal Ekonomi Lingkungan, 13(2), 1-15.

Fitriani, A., Daryanto, H. K., Nurmalina, R., \& Susilowati, S. (2014a). Struktur, Perilaku dan Kinerja Industri Broiler Indonesia: Pendekatan Model Simultan (Structure, Conduct and Performance of Indonesian Broiler Industry: A Simultaneous Approach Model). Jurna Agro Ekonomi, 32(2), 167-186. https://doi.org/http://dx.doi.org/10.21082/jae.v32n2.2014.167-186

Fitriani, A., Daryanto, H. K., Nurmalina, R., \& Susilowati, S. H. (2014b). Impact on Increasing Concentration in Indonesian Broiler Industry. International Journal of Poultry Science, 13(4), 191-197. 
http://free-journal.umm.ac.id/files/file/Impact on Increasing Concentration in Indonesian Broiler Industry.pdf

Hikmah, S. F. (2019). Dinamika Maro Bathi Sistem Nggadoh Kambing Berdasarkan Hukum Adat sebagai Upaya Mengurangi Pengangguran di $\begin{array}{lllll}\text { Kabupaten } & \text { Banyuwangi. Jurnal } & \text { Istiqro, }\end{array}$ https://doi.org/10.30739/istiqro.v5i2.417

Ilham, N. (2015). Kebijakan pemerintah terhadap usaha unggas skala kecil dan kesehatan lingkungan di Indonesia. Wartazoa, 25(2), 95-105. https://doi.org/10.14334/wartazoa.v25i2.1146

KPPU [Komisi Pengawas Persaingan Usaha]. (2016). Industri Unggas di kuasai dua pemain besar (Poultry Industry is controlled by two big players). http://bisniskeuangan.kompas.com/read/2016/09/14/185135926/kppu.industri. unggas.indonesia.dikuasai.dua.pemain.besar. Diunduh pada Rabu 15 November 2016.(in Indonesian).

Martindah, E., \& Basuno, E. (2014). Biosecurity Level of Poultry Production Cluster (PPC) in West Java, Indonesia. International Journal of Poultry Science, 13(7), 408-415. http://free-journal.umm.ac.id/files/file/Biosecurity Level of Poultry Production Cluster (PPC) in West Java, Indonesia.pdf

Muryani, Hakim, D., Sanim, B., \& Syaukat, Y. (2012). Dampak Flu Burung Terhadap Perekonomian: Tinjauan Aspek Lingkungan, Sosial dan Ekonomi Nasional (The Impact of Avian Influenza on Indonesian Economy: Socio-Economic and Environmental Perspective). Jurnal Ekonomi Dan Bisnis Airlangga, 22(2), 106-115. https://doi.org/http://dx.doi.org/10.20473/jeba.V22I22012.4317

Parikh, J., May, P., \& Motta, R. da. (1996). Consumption Patterns: The Driving Force of Environmental stress. Pricing The Planet, 39-48.

Puskadagri. (2016). Kajian Kebijakan Persaingan Usaha di Sektor Perunggasan. Pusat Pengkajian Perdagangan Dalam Negeri (Review of Business Competition Policy in Poultry Sector). Badan Pengkajian dan Pengembangan Perdagangan. Kementerian Perdagangan Republik Indonesia.(in Indonesian).

Rodríguez, U.-P. E., Garcia, Y. T., Garcia, A. G., \& Tan, R. L. (2006). Can Trade Policies Soften the Economic Impacts of an Avian Influenza Outbreak? Simulations From a CGE Model of the Philippines. Asian Journal of Agriculture and Development, 4(2), 41-50. https://ageconsearch.umn.edu/record/166011/

Rusastra, W., Yusdja, Y., Sumaryanto, Y., Darmawan, D. H., \& Djatiharti, A. (1988). 
Analisa Finansial dan Ekonomi Kelembagaan Perusahaan Inti Rakyat Perunggasan (Financial Analysis and Institutional Economics of the Core Society of Poultry)

Salim, E. (2005). Preface: Looking Back to Move Forward. In The Politics and Economics of Indonesia's Natural Resources. https://doi.org/https://doi.org/10.1355/9789812305497

Saptana, \& Ashari, A. (2007). Pembangunan Pertanian Berkelanjutan Melalui Kemitraan Usaha (Sustainable Agricultural Development Through Agribusiness Partnership). Jurnal Litbang Pertanian, 26(4), 123-130. http://203.190.36.42/publikasi/p3264071.pdf

Saptana, Basuno, E., \& Yusdja, Y. (2005). Dampak Ekonomi Flu Burung Terhadap Kinerja Industri Perunggasan di Provinsi Jawa Tengah (Suatu Kajian Atas Kasus Flu Burung di Kabupaten. SOCA (Jurnal Sosial Ekonomi Pertanian Dan Agribisnis), 5, 283-294.

Saptana, \& Daryanto, A. (2013). Dinamika Kemitraan Usaha Agribisnis Berdayasaing dan Berkelanjutan (The Dynamics of Agribusiness Partnership Competitiveness and Sustainable) (I. W. Rusastra \& Syahyuti (eds.)). Pusat Sosial Ekonomi dan Kebijakan Pertanian.

Saptana, \& Ilham, N. (2016). Pengembangan Sistem Integrasi Tanaman Tebu-Sapi Potong di Jawa Timur. Analisis Kebijakan Pertanian, 13(2), 147. https://doi.org/10.21082/akp.v13n2.2015.147-165

Saptana, Maulana, M., \& Ningsih, R. (2017). Analisis Produksi dan Pemasaran Komoditas Broiler diJawa Barat (Production and Marketing Analysis of Broiler Commodities in West Java). Jurnal Manajemen Dan Agribisnis, 14(2), 152-152. https://doi.org/10.17358/jma.14.2.152

Saptana, \& Yofa, R. D. (2016). Penerapan Konsep Manajemen Rantai Pasok Pada Produk Unggas (Implementation of Supply Chain Management Concept on Poultry Products). Forum Penelitian Agro Ekonomi, 34(2), 143-161. https://doi.org/10.21082/fae.v34n2.2016.143-161

Simatupang, P. (1995). Industrialisasi pertanian sebagai strategi agribisnis dan pembangunan pertanian dalam era globalisasi. In Orasi Pengukuhan Ahli Peneliti Utama Puslit Sosek Pertanian. Badan Litbang Pertanian.

Simatupang, P., Muharminto, P., Syam, A., Muharminto, Purwoto, Hardono, H., Indraningsih, K., Jamal, E., \& Elizabeth, R. (1998). Koordinasi Vertikal sebagai Strategi untuk Meningkatkan Dayasaing dan Pendapatan dalam Era Globalisasi Ekonomi (Kasus Agribisnis Kopi).

Tangendjaja, B. (2010). Global Competitiveness of Poultry Production in South 
East Asia Countries. Wartazoa, 20, 161-171.

Tribunnews. (2017). Jumlah penduduk indonesia bertambah jadi 262 juta jiwa lebih (Indonesia population increased up to more than 262 million people). http://jogja.tribunnews.com/2017/08/02/hingga-juli-2017-jumlah-penduduk-i ndonesia-bertambah-jadi-262-juta-jiwa-lebih. Diunduh pada Rabu 15 November 2017. (in Indonesian).

Turner, R., Pearce, D., \& Bateman, I. (1994). Environmental economics: an elementary introduction. https://www.cabdirect.org/cabdirect/abstract/19931861592

Wang, L., Liu, Q., Zheng, H. E., Wu, J., \& Li, X. (2014). Development of Poultry Production Clusters in China: A Policy Review. International Journal of Poultry Science, 13(5),

292-298.

https://pdfs.semanticscholar.org/87b1/bdd5f08ae223db71d7bebf3ed15330c77c b5.pdf

Wei, H., \& Aengwanich, W. (2012). Biosecurity Evaluation of Poultry Production Cluster (PPCs) in Thailand. International Journal of Poultry Science, 11(9), 582-588. http://free-journal.umm.ac.id/files/file/Biosecurity Evaluation of Poultry Production Cluster (PPCs) in Thailand.pdf

Yunianto, A. (2015). Urgensi Tradisi Gaduh Bagi Hasil Hewan Ternak dalam Kaitannya dengan Peningkatan Pendapatan Masyarakat di Dusun Jeruk Wangi Desa Bedono Kecamatan Jambu Kabupaten Semarang [Fakultas Hukum Universitas Negeri Semarang]. http://lib.unnes.ac.id/21667/

Yusdja, Y. (1984). Analisis Fungsi Keuntungan Usaha Ternak Ayam Petelur (Function Analysis of the Profit of Laying Chicken Farms). Institut Pertanian Bogor.

Yusdja, Y., Ilham, N., \& Sajuti, R. (2004). ). Tinjauan Penerapan Kebijakan Industri Ayam Ras: Antara Tujuan dan Hasil (Implementation Overview of Chicken Race Industry Policy: Between Goals And Results). Forum Penelitian Agro Ekonomi, 22(1), 22-36. https://doi.org/10.21082/fae.v22n1.2004.22-36

Yusdja, Y., Sajuti, R., Iqbal, M., \& Tambunan, M. (2000). Perumusan Kebijaksanaan dan Model Restrukturisasi Industri Ternak Unggas Nasional (Policy Formulation and Restructuring Model of National Poultry Livestock Industry). 